\title{
Antimicrobial susceptibility patterns among bacteria isolated from intensive care units of the largest teaching hospital at the northwest of Iran
}

\author{
Hadi Hamishehkar ${ }^{1}$, Pegah Shadmehr², Ata Mahmoodpoor ${ }^{3}$, Simin Ozar Mashayekhi ${ }^{4}$, Taher \\ Entezari-Maleki ${ }^{1,5}$,*
}

\begin{abstract}
${ }^{1}$ Applied Drug Research Center, Tabriz University of Medical Sciences, Tabriz, Iran, ${ }^{2}$ Student Research Committee, Tabriz University of Medical Sciences, Tabriz, Iran, ${ }^{3}$ Faculty of Medicine, Tabriz University of Medical Sciences, Tabriz, Iran, ${ }^{4}$ Tabriz Health Services Management Research Center, Tabriz University of Medical Sciences, Tabriz, Iran, ${ }^{5}$ Cardiovascular Research Center, Tabriz University of Medical Sciences, Tabriz, Iran
\end{abstract}

\begin{abstract}
This study was conducted to determine the antimicrobial susceptibility patterns among common pathogens in the intensive care units (ICUs) of a university hospital in northwestern Iran. A retrospective study was done on laboratory records of patients with nosocomial infection who were admitted to five ICUs of Imam Reza Hospital during a 21-month period from March 2010 to January, 2012. A total number of 556 isolates from 328 patients were evaluated. The most common sites of infections included respiratory $(51.7 \%)$, urinary $(24.8 \%)$, and blood $(10.4 \%)$. The most frequently isolated microorganisms were Enterobacter aerogenes (50.6\%) followed by Escherichia coli (16.7\%) and Pseudomonas aeruginosa (7.5\%). Staphylococcus aureus was the most frequent pathogen among gram-positives (39.7\%). The rate of methicillin-resistant Staphylococcus aureus (MRSA) was 87.5\%. Multidrug-resistant (MDR) gram-negative bacteria were documented in 25.8\% of Acinetobacter, 20\% of Klebsiella, and 16.6\% of Pseudomonas. The most active antimicrobials were vancomycin $(93.5 \%)$ followed by amikacin (71.5\%) and gentamicin (46\%). The overall antibiotic susceptibility was as follows: $36 \%$ ciprofloxacin, $19 \%$ imipenem, $20 \%$ trimethoprim-sulfamethoxazole, $20.5 \%$ ceftazidime, and $12 \%$ ceftriaxone. Due to the high rate of antimicrobial resistance in the ICU setting, more surveillance and control of the use of antimicrobials is needed to combat infections.
\end{abstract}

Uniterms: Intensive care units/anti-infective agents/cross infection. Hospital University/Iran.

\section{INTRODUCTION}

Patients admitted to intensive care units (ICUs) are more vulnerable to various nosocomial infections because of their underlying illnesses and exposure to various invasive medical devices (Jatin, Mary, 2012; Archibald et al., 1997; Fridkin, 2001; Kollef, Fraser, 2001; Rhomberg et al., 2006).

Hospital infections affect approximately two million patients annually and lead to 90,000 deaths and a cost of $\$ 4.5$ to $\$ 5.7$ billion according to reports from the United States (Weinstein, 1998; Jarvis, 2001). They involve

\footnotetext{
*Correspondence: T. Entezari-Maleki. Cardiovascular Research Center, Faculty of Pharmacy. Tabriz University of Medical Sciences, Tabriz, Iran, Daneshgah Street, 55617, Tabriz, Iran. E-mail: tentezari@gmail.com
}

5-10\% of ICU patients (CDC, 1992; Stone, Larson, Kawar, 2002).

Antibiotics are the mainstay tools in the management of infections. Disappointingly, a number of studies have reported inappropriate uses of antimicrobials as well as the emergence of antibiotic resistance in most parts of the world (Tunger et al., 2009; Bergman et al., 2006). Today, the emergence of multidrug-resistant (MDR) gramnegative and methicillin-resistant Staphylococcus aureus (MRSA) pathogens has become a major public health concern. Moreover, they negatively influence patients' outcomes and increase the length of hospital stays and healthcare costs (Giske et al., 2008; De Kraker et al., 2011; Resch, Wilke, Fink, 2009; Mulvey, Simor, 2009).

Many studies have also showed that controlled use of antibiotics leads to improved microorganism sensitivity 
to antimicrobial agents (Lee et al., 2010; Takesue et al., 2010). The emergence of resistant pathogens and their negative impact on patient survival and healthcare costs need the evaluation of antimicrobial susceptibility in each health center and hospital in order to control infection. Therefore, this study assessed antimicrobial susceptibility patterns in the ICUs of the largest teaching hospital in northwestern Iran. To the best of the authors' knowledge, this is the first report of bacterial resistance in ICUs at this location.

\section{MATERIAL AND METHODS}

\section{Study Design and Setting}

A retrospective study was done on laboratory records of the positive cultures patients with nosocomial infection who were admitted at the five ICUs of Imam Reza Hospital, a 500-bed tertiary care hospital affiliated to Tabriz University of Medical Sciences during a 21 -month period (March 2010 to January 2012). This study was approved in the ethic committee of the university.

\section{Data and Sample Collection}

For doing the study a questionnaire form was designed in order to record patients' data included age, sex, file number, ward, culture results, site of infection, diagnostic species, and antibiogram test results. Prescribed drugs for ICU cultures were demonstrated using the hospital information system (HIS). All samples were taken in aseptic conditions. The sources of specimen included blood, urine, sputum, bronchial washing, wound, catheter, cerebrospinal fluid (CSF), tracheal, peritoneal, pleural, and synovial fluids.

\section{Antimicrobial Susceptibility Testing}

The Kirby-Bauer disk diffusion method was used to test antimicrobial susceptibility (in Mueller-Hinton agar medium, Merck, Germany) according to the guidelines of the National Committee for Clinical Laboratory Standards (NCCLS, 1997).

The performed antibiogram disks (Himedia laboratories, Mumbai, India) included vancomycin (V, $30 \mathrm{mcg}$ ), ciprofloxacin (CIP, $5 \mathrm{mcg}$ ), clindamycin (CD, $2 \mathrm{mcg}$ ), trimethoprim-sulfamethoxazole(SXT, $30 \mathrm{mcg}$ ), gentamicin (GM, $10 \mathrm{mcg}$ ), ofloxacin (OFX, $5 \mathrm{mcg}$ ), penicillin $\mathrm{G}(\mathrm{P}, 10 \mathrm{mcg})$, oxacillin (OXA, $5 \mathrm{mcg}$ ), amikacin (AMK, $30 \mathrm{mcg}$ ), cefotaxime (CTX, $30 \mathrm{mcg}$ ), ceftazidime
(CAZ, $30 \mathrm{mcg}$ ), ceftriaxone (CTR, $30 \mathrm{mcg}$ ), cefazolin (CZ, 30mcg), chloramphenicol (CHL, $30 \mathrm{mcg}$ ), piperacillin (PIP, $100 \mathrm{mcg}$ ), imipenem (IPM, 10mcg), nitrofurantoin (FM, $50 \mathrm{mcg})$, ampicillin (AM, $10 \mathrm{mcg}$ ) and rifampin (RIF, $5 \mathrm{mcg}$ ).

\section{Determination of Pattern of Antibiotic Prescriptions}

A clinical pharmacist and two intensive care subspecialists evaluated the appropriateness of prescribed antibiotics based on result of each isolated cultures from ICU patients.

Patterns of antibiotic prescription based on culture results were divided into four groups: Group 1) Adherence with culture results, according to culture the drug is added or discontinued. Group 2) Not adherence with culture results as follows: 2-1) No change in medication; While, culture results showed resistance to antibiotics or following antibiotic therapy. We need to change the antibiotics but physician did not notice to culture results and antibiotics continued. 2-2) inappropriate changes in medication: the doctor noticed that you need to change the antibiotic, but changes were not accordance to protocols and appropriate drug that affect antibiotic therapy to improve patient has not chosen.

Group 3) rational change without culture result guide: due to the lack of laboratory antibiogram test for all antibiotics, a rationale prescription of drugs by doctors was made.

Group 4) No judgment: Because there was no complete transparency in the medical record for patient, judgment in this case considered impossible by experts.

Antibiotics utilization rates in ICUs were determined by Defined Daily Dose (DDD) per 100 bed-days.

\section{Data Analysis}

Data were processed in SPSS 16. Results were shown as standard deviation for quantitative variables and percentage for categorical variables.

\section{RESULTS}

A total number of 556 cultures isolated from 328 patients who were admitted at the five ICUs of the hospital were included in the study. Of which, 55.5\% $(n=182)$ were males and $44.5 \%(n=146)$ were females. The mean (SD) forage of the patients was $54 \pm 19.5$ years old. Data were collected from the five ICUs of the hospital as follows: $31.1 \%(n=102)$ from brain ICU, 
$22.6 \%(n=74)$ neurology ICU, 28.4\% (n=93) lung ICU, $16.5 \%(n=54)$ surgery ICU and $1.5 \%(n=5)$ from the general ICU. As shown, the brain ICU has the greatest number of patients.

The most common sites of infection included respiratory $(40.6 \%)$, urine $(24.8 \%)$ and blood $(10.4 \%)$ followed by sputum (4.7\%), CSF (4.7\%), plural (3.9\%), bronchial washing $(3.6 \%)$, catheter $(2.7 \%)$, abscess $(2.2 \%)$, wound $(2 \%)$, peritoneal $(0.4 \%)$ and synovial $(0.2 \%)$ specimen. The result of Gram staining showed that the majority of cultured samples $(86.8 \%, n=483)$ were Gram-negative bacteria as well as $13.2 \%(\mathrm{n}=74)$ were Gram-positive.

The most frequently isolated microorganisms were Enterobacter aerogenes $(50.7 \%, \mathrm{n}=282)$ followed by Escherichia coli (16.7\%) and Pseudomonas aeruginosa $(7.5 \%)$. The prevalence of isolated microorganisms is given in Table I.

TABLE I - Bacterial typing of ordered cultures Bacterial type

\begin{tabular}{|c|c|c|}
\hline \multirow{8}{*}{ 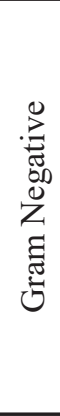 } & Enterobacter aerogenes, $\mathrm{n}(\%)$ & $282(50.7)$ \\
\hline & Esherichia coli, $\mathrm{n}(\%)$ & $93(16.7)$ \\
\hline & Pseudomonas aeruginosa, $\mathrm{n}(\%)$ & $42(7.6)$ \\
\hline & Acintobacter spp. n (\%) & $31(5.6)$ \\
\hline & Unclassified Gram-negative bacteria, n (\%) & $25(4.5)$ \\
\hline & Klebsiella spp. n (\%) & $5(0.9)$ \\
\hline & Enterobacter + E.coli, $\mathrm{n}(\%)$ & $5(0.9)$ \\
\hline & Total, n (\%) & $483(86.9)$ \\
\hline \multirow{7}{*}{ 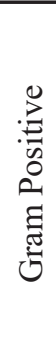 } & Staphylococcu saureus, n (\%) & $29(5.2)$ \\
\hline & Staphylococcus epidermidis, n (\%) & $24(4.3)$ \\
\hline & Enterococcus spp. $\mathrm{n}(\%)$ & $11(2.0)$ \\
\hline & Unclassified Gram-positive bacteria, n (\%) & $5(0.9)$ \\
\hline & Streptococcus spp. n (\%) & $3(0.5)$ \\
\hline & Streptococcus pnemoniae, $\mathrm{n}(\%)$ & $1(0.2)$ \\
\hline & Total, n (\%) & $73(13.1)$ \\
\hline
\end{tabular}

Among Gram-positives, Staphylococcus aureus was the most frequently isolated pathogen $(39.7 \%, n=29)$ followed by Staphylococcus epidermidis. Susceptibility rates of Gram-positive and Gram-negative microorganisms are shown in Table II and III respectively. Based on these findings, rate of methicillin resistance Staphylococcus aureus (MRSA) was $87.5 \%$. However, all cases of Staphylococcus aureus and $90 \%$ of Staphylococcus epidermidis were sensitive vancomycin.

In the present study, multidrug resistant (MDR) Gram-negative bacilli were documented in $25.8 \%$ of Acinetobacter, $20 \%$ of Klebsiella and $16.6 \%$ of
Pseudomonas. The susceptibility rate of Enterobacter, Escherichia coli and Pseudomonas aeruginosa to imipenem were $16.4 \%, 16.6 \%$ and $46 \%$ respectively. These rates for ciprofloxacin were $34.5 \%, 43.5 \%$, and $56.5 \%$ and to amikacin were $64.5 \%, 88 \%$, and $62.5 \%$ respectively. Regarding gentamicin, these susceptibility rates were $42.5 \%, 53.7 \%$, and $38.5 \%$ respectively.

Overall susceptibility rates of the microorganisms isolated from the ICUs are also shown in table IV. The most active antimicrobials were vancomycin $(93.5 \%)$ followed by amikacin $(71.5 \%)$ and gentamicin $(46 \%)$. The overall susceptibility of isolated microorganisms to regular important antibiotics was as follows: $36 \%$ for ciprofloxacin, $19 \%$ for imipenem, 20\% for trimethoprimsulfamethoxazole, $20,5 \%$ for ceftazidime, and $12 \%$ for ceftriaxone.

The most Staphylococcus strains were observed in lung and blood samples (31\% and $17.2 \%$ respectively).

Enterobacter and E.coli were the most commonly isolated pathogens from urine samples $(37.7 \%$ and $36.2 \%$ respectively as well as the most frequently isolated microorganisms from lung samples were Enterobacter (52.7\%) followed by Pseudomonas aeruginosa (10.2\%) and Acinetobacter (9.1\%). Entrobacter aerogenes was the most common strain in all samples. Entrobacter aerogenes and E.coli was the most commonly detected microorganisms in most ICUs.

Pattern of antibiotic prescription showed that only $22.5 \%$ of prescriptions were in accordance with culture results and $34.5 \%$ were not adherence with culture results. Moreover, in $38 \%$ of prescriptions logical changes were made without culture result guide. In 5\%, no judgment could be made.

The rate of antibiotics utilization included as follows: ciprofloxacin ( $8.7 \mathrm{mg}$ per 100 bed-days), meropenem $(5.4 \mathrm{mg}$ per 100 bed-days), cefepime (4.2 mg per 100 bed-days), imipenem (3.1 mg per 100 bed-days), ceftazidime (1.9 mg per 100 bed-days), amikacin ( $0.9 \mathrm{mg}$ per 100 bed-days), gentamicin ( $0.8 \mathrm{mg}$ per 100 bed-days), ceftriaxone ( $8 \mathrm{mg}$ per 100 bed-days), vancomycin (4.3 mg per 100 bed-days), piperacillin-tazobactam (2.8 mg per 100 bed-days).

\section{DISCUSSION}

To the best of the authors' knowledge, this is the first report from the ICUs of the largest teaching hospital in northwestern Iran. The result of this study highlighted the important key role of rational prescription of antibiotics. This matter becomes more important when it concerns the emergence of antimicrobial resistance produced by gramnegative bacilli and MRSA strains (Giske et al., 2008; De 
TABLE II - Susceptibility rates of the most common Gram-positive cocci isolated from the ICUs

\begin{tabular}{|c|c|c|c|c|c|c|c|}
\hline & & \multicolumn{6}{|c|}{ Organisms } \\
\hline & & S. aureus & S. epidermidis & Enterococcus & Streptocococcus & S.pnemoniae & $\begin{array}{c}\text { Unclassified } \\
\text { Gram positive } \\
\text { bacteria }\end{array}$ \\
\hline$\overline{\operatorname{Disc} n}$ & & 29 & 24 & 11 & 3 & 1 & 5 \\
\hline \multirow[t]{2}{*}{ AMP } & $\mathrm{S}$ & 2 & - & - & - & 1 & - \\
\hline & $\mathrm{R}$ & 7 & 1 & - & - & - & - \\
\hline \multirow[t]{2}{*}{ IPM } & $\mathrm{S}$ & - & - & - & - & 1 & - \\
\hline & $\mathrm{R}$ & 3 & 1 & _- & _- & _- & _- \\
\hline \multirow[t]{2}{*}{ AMK } & S & 2 & 1 & - & - & - & - \\
\hline & $\mathrm{R}$ & _- & 1 & - & - & - & - \\
\hline \multirow[t]{2}{*}{ GEN } & $\mathrm{S}$ & 3 & 1 & 1 & 1 & 1 & _ \\
\hline & $\mathrm{R}$ & 10 & 4 & - & 1 & _- & _- \\
\hline \multirow[t]{2}{*}{ CHL } & S & 13 & 1 & 1 & 1 & _- & _- \\
\hline & $\mathrm{R}$ & 1 & - & 1 & - & - & - \\
\hline \multirow[t]{2}{*}{ SXT } & $\mathrm{S}$ & 7 & 5 & _- & 1 & 1 & _- \\
\hline & $\mathrm{R}$ & 8 & 1 & 3 & 2 & _- & - \\
\hline \multirow[t]{2}{*}{ NIT } & S & 1 & 3 & 2 & - & - & - \\
\hline & $\mathrm{R}$ & _- & _- & _- & _- & _- & _- \\
\hline \multirow[t]{2}{*}{ CIP } & S & 2 & 1 & - & 1 & - & - \\
\hline & $\mathrm{R}$ & 8 & 4 & 1 & _- & _- & _- \\
\hline \multirow[t]{2}{*}{ CLI } & S & 4 & 1 & 1 & _- & _- & - \\
\hline & $\mathrm{R}$ & 9 & 4 & - & 1 & - & - \\
\hline \multirow[t]{2}{*}{ VAN } & S & 23 & 9 & 1 & 2 & 1 & _- \\
\hline & $\mathrm{R}$ & - & 1 & 1 & - & - & - \\
\hline \multirow[t]{2}{*}{ RIF } & $\mathrm{S}$ & 1 & - & - & - & - & - \\
\hline & $\mathrm{R}$ & 2 & - & - & - & - & - \\
\hline \multirow[t]{2}{*}{ OXA } & S & 1 & - & - & - & - & - \\
\hline & $\mathrm{R}$ & 15 & 6 & _- & 1 & 1 & _- \\
\hline \multirow[t]{2}{*}{ PEN } & S & - & - & - & - & - & - \\
\hline & $\mathrm{R}$ & 1 & 2 & - & 2 & 1 & - \\
\hline \multirow[t]{2}{*}{ CEF } & $\mathrm{S}$ & - & - & - & - & - & - \\
\hline & $\mathrm{R}$ & 1 & $\ldots$ & - & - & - & $\ldots$ \\
\hline
\end{tabular}

$\mathrm{R}=$ Resistant, $\mathrm{S}=$ Sensitive, $-=$ Not measured or not reported, $\mathrm{AMP}=$ Ampicillin, $\mathrm{IPM}=$ Imipenem, $\mathrm{AMK}=\mathrm{Amikacin}, \mathrm{GEN}=$ Gentamicin, $\mathrm{CHL}=$ Chloramphenicol, $\mathrm{SXT}=$ trimethoprim-sulfamethoxazole, NIT $=$ Nitrofurantoin, $\mathrm{CIP}=\mathrm{Ciprofloxacin}, \mathrm{CLI}=$ Clindamycin, $\mathrm{VAN}=$ Vancomycin, $\mathrm{RIF}=$ Rifampine, $\mathrm{A}=$ Oxacillin, $\mathrm{PEN}=$ Penicillin, $\mathrm{CEF}=$ Cefazolin .

Kraker et al., 2011; Resch, Wilke, Fink, 2009; Mulvey, Simor, 2009). Hence, the detection of antimicrobial resistance patterns in every hospital plays an important role in the management of infections.

Hospital-acquired infections are life-threatening conditions that involve patients, especially those admitted to ICUs. Respiratory pathogens are responsible for about one-third of ICU infections (Garner et al., 1998; Flanders, Collard, Saint, 2006). In the present study, the most common site of infection was the respiratory tract (51.7 $\%$ ); this result is in agreement with other studies conducted indifferent countries including Turkey (38.8 \%) (Gunseren et al., 1999), India (29.7\%) (Orrett, 2002), Oman (65\%) (Al-Lawati, Crouch, Elhag, 2000), Italy (91\%) (Bassetti et 
TABLE III - Susceptibility rates of Gram-negative bacilli isolated from the ICU

\begin{tabular}{|c|c|c|c|c|c|c|c|c|}
\hline & & \multicolumn{7}{|c|}{ Organisms } \\
\hline & & P. aeruginosa & E. coli & Klebsiella & Acintobacter & Enterobacter & $\begin{array}{c}\text { Enterobacter }+ \\
\text { E.coli }\end{array}$ & $\begin{array}{c}\text { Unclassified } \\
\text { Gram negative } \\
\text { bacteria }\end{array}$ \\
\hline Disc $n$ & & 42 & 93 & 5 & 31 & 282 & 5 & 25 \\
\hline \multirow[t]{2}{*}{ CAZ } & $\mathrm{S}$ & 3 & 8 & - & 1 & 10 & - & 2 \\
\hline & $\mathrm{R}^{\mathrm{b}}$ & 6 & 12 & 1 & 11 & 55 & - & 4 \\
\hline \multirow[t]{2}{*}{ AMP } & $\mathrm{S}$ & 1 & - & - & - & 4 & - & 1 \\
\hline & $\mathrm{R}$ & 10 & 19 & 1 & 15 & 49 & 1 & 4 \\
\hline \multirow[t]{2}{*}{ CTX } & $\mathrm{S}$ & 4 & 4 & - & - & 5 & - & 1 \\
\hline & $\mathrm{R}$ & 8 & 23 & 2 & 12 & 41 & 2 & 10 \\
\hline \multirow[t]{2}{*}{ IPM } & $\mathrm{S}$ & 6 & 2 & - & - & 12 & - & - \\
\hline & $\mathrm{R}$ & 7 & 10 & 1 & 4 & 61 & 1 & 1 \\
\hline \multirow[t]{2}{*}{ AMK } & $\mathrm{S}$ & 20 & 66 & 3 & 20 & 111 & 3 & 11 \\
\hline & $\mathrm{R}$ & 12 & 9 & 1 & 8 & 61 & 1 & 2 \\
\hline \multirow[t]{2}{*}{ GEN } & $\mathrm{S}$ & 10 & 29 & 1 & 8 & 62 & 1 & 9 \\
\hline & $\mathrm{R}$ & 16 & 25 & 1 & 8 & 84 & 1 & - \\
\hline \multirow[t]{2}{*}{$\mathrm{CHL}$} & S & 1 & 16 & 2 & - & 24 & - & 1 \\
\hline & $\mathrm{R}$ & 14 & 11 & 1 & 12 & 78 & 2 & 7 \\
\hline \multirow[t]{2}{*}{ SXT } & $\mathrm{S}$ & 7 & 12 & - & 1 & 20 & - & 1 \\
\hline & $\mathrm{R}$ & 17 & 47 & 2 & 18 & 109 & 3 & 9 \\
\hline \multirow[t]{2}{*}{ NIT } & $\mathrm{S}$ & - & 33 & 1 & - & 16 & - & - \\
\hline & $\mathrm{R}$ & 7 & 6 & - & 2 & 25 & 1 & 2 \\
\hline \multirow[t]{2}{*}{ CIP } & $\mathrm{S}$ & 13 & 23 & - & 3 & 47 & 1 & 2 \\
\hline & $\mathrm{R}$ & 10 & 30 & 1 & 13 & 89 & 3 & _- \\
\hline \multirow[t]{2}{*}{ CLI } & $\mathrm{S}$ & - & - & - & - & - & - & - \\
\hline & $\mathrm{R}$ & - & 2 & - & 3 & 3 & 1 & 2 \\
\hline \multirow[t]{2}{*}{ CET } & $\mathrm{S}$ & 3 & 1 & - & 1 & 8 & - & 1 \\
\hline & $\mathrm{R}$ & 6 & 12 & 1 & 6 & 79 & _- & _ \\
\hline \multirow[t]{2}{*}{ CEZ } & $\mathrm{S}$ & 3 & 6 & - & - & 9 & - & 1 \\
\hline & $\mathrm{R}$ & 10 & 11 & 1 & 4 & 49 & - & 4 \\
\hline \multirow[t]{2}{*}{ RIF } & $\mathrm{S}$ & 1 & - & 1 & 3 & 26 & 2 & 2 \\
\hline & $\mathrm{R}$ & 3 & 11 & _ & _ & 15 & _ & 2 \\
\hline \multirow[t]{2}{*}{ OXA } & $\mathrm{S}$ & - & - & - & - & 1 & - & - \\
\hline & $\mathrm{R}$ & 9 & 11 & 1 & 6 & 53 & 1 & 1 \\
\hline \multirow[t]{2}{*}{ PEN } & $\mathrm{S}$ & - & - & - & - & - & - & - \\
\hline & $\mathrm{R}$ & - & - & - & - & - & - & - \\
\hline \multirow[t]{2}{*}{ PIP } & $\mathrm{S}$ & - & - & - & - & - & - & - \\
\hline & $\mathrm{R}$ & _ & $\ldots$ & _ & _ & _- & _ & _ \\
\hline
\end{tabular}

$\mathrm{R}=$ Resistant, $\mathrm{S}=$ Sensitive, $-=$ Not measured or not reported, $\mathrm{AMK}=$ Amikacin, $\mathrm{GEN}=$ Gentamicin, $\mathrm{SXT}=$ trimethoprimsulfamethoxazole, $\mathrm{CIP}=$ Ciprofloxacin, $\mathrm{CHL}=$ Chloramphenicol, $\mathrm{CET}=$ Ceftriaxone, $\mathrm{CTX}=$ Cefotaxime $, \mathrm{CAZ}=\mathrm{Ceftazidime}, \mathrm{AMP}=$ Ampicillin, IPM= Imipenem, OXA= Oxacillin, $\mathrm{CEZ}=$ Ceftizoxime, NIT = Nitrofurantoin, $\mathrm{VAN}=$ Vancomycin, $\mathrm{CLI}=\mathrm{Clindamycin}$, $\mathrm{PEN}=$ Penicillin, $\mathrm{PIP}=$ piperacillin. 
TABLE IV - Overall susceptibility rates of the microorganisms isolated from the ICUs

\begin{tabular}{|c|c|c|c|c|c|}
\hline \multirow[t]{2}{*}{ Used discs } & \multirow[t]{2}{*}{$\mathrm{n}(\%)$} & \multicolumn{2}{|c|}{ Sensitive } & \multicolumn{2}{|c|}{ Resistant } \\
\hline & & $\mathrm{N}$ & $\%$ & $\mathrm{~N}$ & $\%$ \\
\hline AMK & $333(59.8)$ & 238 & 71.5 & 95 & 28.5 \\
\hline GEN & $278(50.0)$ & 128 & 46.0 & 150 & 54.0 \\
\hline SXT & $275(49.4)$ & 55 & 20.0 & 220 & 80.0 \\
\hline CIP & $259(46.5)$ & 93 & 35.0 & 166 & 65.0 \\
\hline $\mathrm{CHL}$ & $188(33.8)$ & 60 & 32.0 & 128 & 68.0 \\
\hline CET & $123(22.1)$ & 15 & 12.2 & 108 & 87.8 \\
\hline CTX & $117(21.0)$ & 15 & 12.8 & 102 & 87.2 \\
\hline CAZ & $117(21.0)$ & 24 & 20.5 & 93 & 79.5 \\
\hline AMP & $116(19.8)$ & 9 & 7.8 & 107 & 92.2 \\
\hline IPM & $111(20.0)$ & 21 & 19.0 & 90 & 81.0 \\
\hline OXA & $107(19.3)$ & 2 & 1.8 & 105 & 98.2 \\
\hline CEZ & $100(18.0)$ & 19 & 19.0 & 81 & 81.0 \\
\hline NIT & $99(17.8)$ & 56 & 56.5 & 43 & 43.5 \\
\hline VAN & $39(7.1)$ & 36 & 92.3 & 3 & 7.7 \\
\hline CLI & $31(5.6)$ & 6 & 19.4 & 25 & 80.6 \\
\hline PEN & $6(1.1)$ & - & - & 6 & 100 \\
\hline PIP & $1(0.2)$ & - & - & 1 & 100 \\
\hline
\end{tabular}

$\mathrm{AMK}=$ Amikacin, $\mathrm{GEN}=$ Gentamicin, $\mathrm{SXT}=$ trimethoprim-sulfamethoxazole, $\mathrm{CIP}=$ Ciprofloxacin, $\mathrm{CHL}=\mathrm{Chloramphenicol}, \mathrm{CET}=$ Ceftriaxone, $\mathrm{CTX}=$ Cefotaxime, $\mathrm{CAZ}=$ Ceftazidime, $\mathrm{AMP}=$ Ampicillin, $\mathrm{IPM}=$ Imipenem, $\mathrm{OXA}=$ Oxacillin, $\mathrm{CEZ}=\mathrm{Ceftizoxime}$, $\mathrm{NIT}=$ Nitrofurantoin, $\mathrm{VAN}=$ Vancomycin $, \mathrm{CLI}=\mathrm{Clindamycin}, \mathrm{PEN}=$ Penicillin, $\mathrm{PIP}=$ piperacillin .

al., 2012), the United States (54.4\%) (Streit et al., 2004), and a separate report from Iran (70.6\%) (Mohammadtaheri et al., 2010).

The SENTRY Antimicrobial Surveillance Program which included 25 ICUs in Europe (1997-1998) and North America (2001) reported S. aureusas the most common pathogen in developed countries followed by $P$. aeruginosa and E. coli (Streit et al., 2004; Fluit et al., 2001). However, this pattern in developing countries such as Brazil (Mendes et al., 2005), Turkey (Kucukates, 2005), Iran (Mohammadtaheri et al., 2010), and other Middle Eastern countries were documented as Pseudomonas and Acinetobacter (Aly, Al-Mousa, Al Asar, 2008; Bayram, Balci, 2006). In the present study, Enterobacter aerogenes followed by E. coli and $P$. aeruginosa were the organisms most frequently recovered from ICUs. In a Serbian report, Enterobacter strains were the bacteria most commonly isolated from ICUs (Djordjevic et al., 2012).

In the current study, Escherichia coli $(36.2 \%)$ and Enterobacter aerogenes (52.7\%) were the isolates most commonly found in urinary and respiratory tracts. These findings are in agreement with those of the study conducted by Streit et al. in North America (Streit et al., 2004). However, in a report from Oman, Escherichia coli and Pseudomonas aeruginosa were the pathogens most commonly found in the urinary and respiratory tracts of ICU patients (Al-Lawati, Crouch, Elhag, 2000). Whereas, Klebsiella and Pseudomonas were the microorganisms most commonly found in the urine of patients admitted to the ICU of Imam Khomeini Hospital in Tehran (Hadadi et al., 2008).

In the current study, $86.2 \%$ of microorganisms isolated from urine were gram-negative bacteria. This finding is in line with a 2003 NNIS study that showed the highest rates of gram-negative infections to be in urine (Gaynes, Edwards, 2005).

The most common gram-positive organisms recovered from the ICUs in this study were $S$. aureus followed by $S$. epidermidis. This result is in agreement with the findings of Mohammadtaheri et al. (2010) and Khalili et al. (2012) in their studies conducted in ICU and infectious ward settings in Iran. ().

In the present study, MRSA made up $87.5 \%$ of all S.aureus isolates. This rate is higher than those reported from Canada (CAN-ICU study) (22.3\%) (Zhanel et al., 
2008), Europe (39\%) (Fridkin, 2001), and the USA (55\%) (Styers et al., 2006), but it is comparable with the report from Turkey (82\%) (Bayram, Balci, 2006). Also, the rate of MRSA in the current study is lower than that report separately from Iran (96.2\%) (Mohammadtaheri et al., 2010).

All MRSA isolates in the current study were susceptible to vancomycin; this is in line with the report from Iran and the CAN-ICU study (Mohammadtaheri et al., 2010; Khalili et al., 2012; Zhanel et al., 2008). The other active agent against MRSA was trimethoprimsulfamethoxazole (46.7\%); this result is similar to that of Mohammadtaheri et al. (51.9\%) (Mohammadtaheriet al., 2010), but it is far from that of the CAN-ICU study (11.7\%) (Zhanel et al., 2008).

Currently, MRSA is an emerging problem associated with a higher rate of mortality and increased durations of hospitalization and healthcare costs (Giskeet al., 2008; De Kraker et al., 2011).This higher rate of MRSA should raise the concerns of health authorities and lead to a larger battle against the propagation of infections.

In the present investigation, the resistance rate of pathogens to imipenem was documented in more than $80 \%$ of isolates; this rate is higher than those of Belgium (13\%) (Glupczynski et al., 2001), Poland (8\%) (Patzer, Dzierzanowska,Turner, 2002), and Turkey (20.8\%) (Kucukates, 2005).

Recent data from Iran revealed that the resistance of microorganisms to imipenem has increased. The susceptibility rates of pathogens to imipenem in earlier studies from Iran were about $98 \%$ and $87.5 \%$ in 2006 and 2008, respectively (Vessal et al., 2006; Hadadi et al., 2008). In 2010, however, the authors of the current study reported the decline of these rates to $2-37 \%$ and $19 \%$, respectively (Mohammadtaheri et al., 2010). Accordingly, it may be concluded that the appearance of pathogens resistant to imipenem is increasing in Iran with the passing of time and consumption of the drug.

Antimicrobial resistance to ciprofloxacin was documented in $65 \%$ of cases. This rate in reports from Iran, Turkey, and Belgium was $76 \%, 29 \%$, and $21 \%$, respectively (Kucukates, 2005; Hadadi et al., 2008; Glupczynski et al., 2001).

The overall resistance rate of antimicrobials was higher in the current study than in other reports (Gunseren et al., 1999; Mendes et al., 2005; Styers et al., 2006; Patzer, Dzierzanowska, Turner, 2002; Gonlugur et al., 2004; Karlowsky et al., 2003). Moreover, the resistance rate to cephalosporins $(79.5 \%-87.8 \%)$ was comparable to that in Iran (Hadadiet al., 2008), but higher than reported in foreign studies (Gunseren et al., 1999; Al-Lawati,
Crouch, Elhag, 2000; Glupczynski et al., 2001; Patzer, Dzierzanowska,Turner, 2002; Gonlugur et al., 2004; Karlowsky et al., 2003; Meric et al., 2005).

Current results also showed that $25.8 \%$ of Acinetobacter, $20 \%$ of Klebsiella, and $16.6 \%$ of Pseudomonas were an MDR gram-negative pathogen. In one study from Turkey from 2000 to $2002,45.4 \%$ of Acinetobacters and $37.7 \%$ of $P$. aeruginosa isolates were MDR (Yaman et al., 2004). In another study conducted in Iran, $80 \%$ of Acinetobacter and 59\% of Klebsiella isolates were MDR (Hadadi et al., 2008). In the Karlowsky et al. (2003) study, among Acinetobacter isolates, the MDR rate was $11.6-24.2 \%$.

MDR gram-negative bacilli-related infections have become a major, rising problem (Thomson, Bonomo, 2005). Despite the growth of MDR strains, very few antimicrobials have been developed to combat these infections (Rubinstein, Vaughan, 2005). The growing body of evidence also proves the development of resistant gram-negative infections without adequate therapeutic options (Falagas et al., 2005). Moreover, MDR gramnegative infections are associated with increased mortality rates, extended durations of hospitalization, and higher healthcare costs (Bergman et al., 2006).

At the end, the results of the present study showed a higher rate of antimicrobial resistance patterns in the ICUs of the largest referral tertiary teaching hospital in northwestern Iran. The irrational use of antibiotics reported in this study may partially justify these results. Therefore, detecting and managing bacterial resistance should be given more attention by clinicians as an important part of any infection control program. Additionally, the development of antibiotic stewardship programs in hospitals, encouragement of rational antibiotic use, and national and local antibacterial surveillances and control programs are recommended to reduce the development of resistant strains and encourage the successful management of infections.

This study has some limitations. Because of its retrospective design, access to clinicians and a medical menu was not possible. Therefore, a clinical judgment about the administration of antibiotics in some cases was not applicable.

\section{CONCLUSION}

This study showed a higher rate of bacterial resistance in the ICUs of a tertiary teaching hospital in Iran. Due to the emergence of resistant microorganisms in ICUs and considering the critical condition of patients in such a setting, more surveillance and control of the use of antibiotics is needed to combat infections. 


\section{ACKNOWLEDGMENTS}

The authors would like to thank Student Research Committee of Tabriz University of Medical Science and Imam Reza hospital staffs for supporting this study.

\section{FINANCIAL DISCLOSURE}

The authors declare no conflicts of interest.

\section{FUNDING/SUPPORT}

None declared.

\section{AUTHOR ROLES}

All authors contributed to the content, drafting, critical revision and approval of this manuscript.

We confirm all patient/personal identifiers have been removed or disguised so the patient/person(s) described are not identifiable and cannot be identified by analyzing the details of these cases.

\section{REFERENCES}

AL-LAWATI, A.M.; CROUCH, N.D.; ELHAG, K.M. Antibiotic consumption and development of resistance among gramnegative bacilli in intensive care units in Oman. Ann. Saudi Med., v.20, n.3-4, p.324-7, 2000.

ALY, N.Y.A.; AL-MOUSA, H.H.; AL ASAR, E.S.M. Nosocomial infections in a medical-surgical intensive care unit. Med. Princ. Pract., v.17, n.5, p.373-377, 2008.

ARCHIBALD, L.; PHILLIPS, L.; MONNET, D.; MCGOWAN, J.E.Jr.; TENOVER, F.; GAYNES, R. Antimicrobial resistance in isolates from inpatients and outpatients in the United States: increasing importance of the intensive care unit. Clin. Infect. Dis., v.24, n.2, p.211-5, 1997.

BASSETTI, M.; DE GAUDIO, R.; MAZZEI, T.; MORACE, G.; PETROSILLO, N.; VIALE, P.; BELLO, G.; LAFACE, S.; ANTONELLI, M. A survey on infection management practices in Italian ICUs. Crit. care, v.16, p.R221, 2012.

BAYRAM, A.; BALCI, I. Patterns of antimicrobial resistance in a surgical intensive care unit of a university hospital in Turkey. BMC Infect. Dis., v.6, p.155, 2006.
BERGMAN, M.; HUIKKO, S.; HUOVINEN, P.; PAAKKARI, P.; SEPPÄLÄ, H.; FINNISH STUDY GROUP FOR ANTIMICROBIAL RESISTANCE (FIRE NETWORK). Macrolide and azithromycin use are linked to increased macrolide resistance in Streptococcus pneumoniae. Antimicrob. Agents Chemother., v.50, n.11, p.3646-3650, 2006.

DE KRAKER, M.E.; DAVEY, P.G.; GRUNDMANN, H.; BURDEN STUDY GROUP. Mortality and hospital stay associated with resistant Staphylococcus aureus and Escherichia coli bacteremia: estimating the burden of antibiotic resistance in Europe. PLoS Med., v.8, n. 10, p.e1001104, 2011.

DJORDJEVIC, Z.; JANKOVIC, S.; GAJOVIC, O.; DJONOVIC, N.; FOLIC, N.; BUKUMIRIC, Z. Hospital infections in a neurological intensive care unit: incidence, causative agents and risk factors. J. Infec. Dev. Countries, v.6, n.11, p.798805, 2012.

FALAGAS, M.E.; BLIZIOTIS, I.A.; KASIAKOU, S.K.; SAMONIS, G.; ATHANASSOPOULOU, P.; MICHALOPOULOS, A. Outcome of infections due to pandrugresistant (PDR) gram-negative bacteria. $B M C$ Infect. Dis., v.5, p.24, 2005.

FLANDERS, S.A.; COLLARD, H.R.; SAINT, S. Nosocomial pneumonia: state of the science. Am. J. Infect. Control., v.34, n.2, p.84-93, 2006.

FLUIT, A.; VERHOEF, J.; SCHMITZ, F.; EUROPEAN SENTRY PARTICIPANTS. Frequency of isolation and antimicrobial resistance of gram-negative and grampositive bacteria from patients in intensive care units of 25 European university hospitals participating in the European arm of the SENTRY Antimicrobial Surveillance Program 1997-1998. Eur. J. Clin. Microbiol. Infect. Dis., v.20, n.9, p.617-625, 2001.

FRIDKIN, S.K. Increasing prevalence of antimicrobial resistance in intensive care units. Crit. Care Med., v.29, p.N64-N68, Supl. 4, 2001.

GARNER, J.S.; JARVIS, W.R.; EMORI, T.G.; HORAN, T.C.; HUGHES, J.M. CDC definitions for nosocomial infections, 1988. Am. J. Infect. Control., v.16, n.3, p.128-140, 1998.

GAYNES, R.; EDWARDS, J.R. Overview of nosocomial infections caused by gram-negative bacilli. Clin. Infect. Dis.,v.41, n.6, p.848-54, 2005. 
GISKE, C.G.; MONNET, D.L.; CARS, O.; CARMELI, Y. Clinical and economic impact of common multidrugresistant gram-negative bacilli. Antimicrob. Agents Chemother, v.52, n.3, p.813-21, 2008.

GLUPCZYNSKI, Y.; DELMEE, M.; GOOSSENS, H.; STRUELENS, M. Distribution and prevalence of antimicrobial resistance among gram-negative isolates in intensive care units (ICU) in Belgian hospitals between 1996 and 1999. Acta Clin. Belg., v.56, n.5, p.297-306, 2001.

GONLUGUR, U.; BAKICI, M.Z.; AKKURT, I.; EFEOGLU, T. Antibiotic susceptibility patterns among respiratory isolates of Gram-negative bacilli in a Turkish university hospital. BMC Microbiol., v.4, p.32, 2004.

GUNSEREN, F.; MAMIKOGLU, L.; OZTURK, S.; YUCESOY, M.; BIBEROGLU, K.; YULUG N.; DOĞANAY, M.; SÜMERKAN, B.; KOCAGÖZ, S.; UNAL, S.; CETIN, S.; CALANGU, S.; KÖKSAL, I.; LEBLEBICIOĞLU, H.; GÜNAYDIN, M. A surveillance study of antimicrobial resistance of gram-negative bacteria isolated from intensive care units in eight hospitals in Turkey. J. Antimicrob. Chemother., v.43, n.3, p.373-8,1999.

HADADI, A.; RASOULINEJAD, M.; MALEKI, Z.; YONESIAN, M.; SHIRANI, A.; KOURORIAN, Z. Antimicrobial resistance pattern of Gram-negative bacilli of nosocomial origin at 2 university hospitals in Iran. Diagn. Microbiol. Infect. Dis., v.60, n.3, p.301-305, 2008.

JATIN, M.V.; MARY, J.F. Overview of antibacterial susceptibility testing. Up To Date, 2012.

KARLOWSKY, J.A.; DRAGHI, D.C.; JONES, M.E.; THORNSBERRY, C.; FRIEDLAND, I.R.; SAHM, D.F. Surveillance for antimicrobial susceptibility among clinical isolates of Pseudomonas aeruginosa and Acinetobacter baumannii from hospitalized patients in the United States, 1998 to 2001. Antimicrob. Agents. Chemother. v.47, n.5, p.1681-8, 2003.

KHALILI, H.; DASHTI-KHAVIDAKI, S.; KARIMZADEH, I.; JAFARI, S.; ABDOLLAHI; A.; SHAHIDI, M.R.; JAHANGARD-RAFSANJANI, Z.; ENTEZARI-MALEKI, T. Changes in 4-year antimicrobial resistance pattern of gram-positive bacteria at the main referral teaching hospital, Tehran, Iran. Acta. Med. Iran., v.50, n.7, p.493-504, 2012.
KOLLEF, M.H.; FRASER, V.J. Antibiotic resistance in the intensive care unit. Ann. Intern. Med. v.134, n.4, p.298314, 2001.

KUCUKATES, E. Antimicrobial resistance among Gramnegative bacteria isolated from intensive care units in a Cardiology Institute in Istanbul, Turkey. Jpn. J. Infect. Dis., v.58, n.4, p.228-231, 2005.

LEE, Y.T.; TSAO, S.M; LIN, H.C.; HUANG, H.J.; LEE, M.C.; HSUEH, P.R. Decline in the incidence of healthcareassociated methicillin-resistant Staphylococcus aureus (HA-MRSA) correlates with deceased antimicrobial consumption at a tertiary care hospital in Taiwan, 20012009. Int. J. Antimicrob. Agents, v.36, n.6, p.523-530, 2010.

MENDES, C.; OPLUSTIL, C.; SAKAGAMI, E.; TURNER, P.; KIFFER, C. Antimicrobial susceptibility in intensive care units: MYSTIC Program Brazil 2002. Braz. J. Infect. Dis., v.9, n.1, p.44-51, 2005.

MERIC, M.; WILLKE, A.; CAGLAYAN, C.; TOKER, K. Intensive care unit-acquired infections: incidence, risk factors and associated mortality in a Turkish university hospital. Jpn. J. Infect. Dis., v.58, n.5, p.297-302, 2005.

MOHAMMADTAHERI, Z;; POURPAKI, M.; MOHAMMADI, F.; NAMDAR, R.; MASJEDI, M.R. Surveillance of Antimicrobial Susceptibility among Bacterial Isolates from Intensive Care Unit Patients of a Tertiary-Care University Hospital in Iran: 2006-2009. Chemotherapy, v.56, n.6, p.478-484, 2010.

MULVEY, M.R.; SIMOR, A.E. Antimicrobial resistance in hospitals: how concerned should we be? CMAJ, v.180, n.4, p.408-415, 2009.

NATIONAL COMMITTEE FOR CLINICAL LABORATORY STANDARDS. NCCLS.. Performance standards for antimicrobial disk susceptibility tests. Approved standard M2-A6. Wayne, Pa: National Committee for Clinical Laboratory Standards, 1997.

ORRETT, F.A. Nosocomial infections in an intensive care unit in a private hospital. West Indian Med. J., v.51, n.1, p.2124, 2002.

PATZER, J.; DZIERZANOWSKA, D.; TURNER, P. Susceptibility patterns of Gram-negative bacteria from a Polish intensive care unit, 1997-2000. Int. J. Antimicrob. Agents., v.19, n.5, p.431-434, 2002. 
CENTERS FOR DISEASE CONTROL. (CDC). Public health focus: surveillance, prevention, and control of nosocomial infections. MMWR Morb. Mortal. Wkly. Rep.,v.41, p.7837, 1992.

RESCH, A.; WILKE, M.; FINK, C. The cost of resistance: incremental cost of methicillin-resistant Staphylococcus aureus (MRSA) in German hospitals. Eur. J. Health Econ.,v.10, n.3, p.287-297, 2009.

RHOMBERG, P.R.; FRITSCHE, T.R.; SADER, H.S.; JONES, R.N. Antimicrobial susceptibility pattern comparisons among intensive care unit and general ward Gram-negative isolates from the meropenem yearly susceptibility test information collection program (USA). Diagn. Microbiol. Infect. Dis., v.56, n.1, p.57-62, 2006.

RUBINSTEIN. E.; VAUGHAN, D. Tigecycline: a novel glycylcycline. Drugs, v.65, p.1317-1336, 2005.

STONE, P.W.; LARSON, E.; KAWAR, L.N. A systematic audit of economic evidence linking nosocomial infections and infection control interventions: 1990-2000. Am. J. Infect. Control., v.30, n.3, p.145-152, 2002.

STREIT, J.M.; JONES, R.N.; SADER, H.S.; FRITSCHE, T.R. Assessment of pathogen occurrences and resistance profiles among infected patients in the intensive care unit: report from the SENTRY Antimicrobial Surveillance Program (North America, 2001). Int. J. Antimicrob. Agents., v.24, n.2, p.111-118, 2004.

STYERS, D.; SHEEHAN, D.J; HOGAN, P.; SAHM, D.F. Laboratory-based surveillance of current antimicrobial resistance patterns and trends among Staphylococcus aureus: 2005 status in the United States. Ann. Clin. Microb. Antimicrob., v.5, p.2, 2006.

TAKESUE, Y.; NAKAJIMA, K.; ICHIKI, K.; ISHIHARA, M.; WADA, Y.; TAKAHASHI, Y.; TSUCHIDA, T.; IKEUCHI, $\mathrm{H}$. Impact of a hospital-wide programme of heterogeneous antibiotic use on the development of antibiotic-resistant Gram-negative bacteria. J. Hosp. Infec., v.75, n.1, p.28-32, 2010 .
THOMSON, J.; BONOMO, R.A. The threat of antibiotic resistance in gram-negative pathogenic bacteria: betalactams in peril! Curr. Opin. Microbiol., v.8, n.5, p.518-524, 2005.

TUNGER, O.; KARAKAYA, Y.; CETIN, C.B.; DINC, G.; BORAND, H. Rational antibiotic use. J. Infect. Dev. Ctries., v.3, n.2, p.88-93, 2009.

VESSAL, G.; AFHAMI, S.; GHOLAMI, K.; SHAFAGHI, B.; HEKMAT-YAZDI, S. Evaluation of antimicrobial resistance among Gram-negative isolates collected from intensive care units and reliability of routine disc susceptibility tests at a teaching hospital in Tehran. Iran J. Pharm. Res., v.5, p.89$100,2006$.

WEINSTEIN, R.A. Nosocomial infection update. Emerg. Infect. Dis., v.4, p.416-420,1998.

JARVIS, W.R. Infection control and changing health-care delivery systems. Emerg. Infect. Dis., v.7, n.2, p.170173,2001 .

YAMAN, A.; TASOVA, Y.; KIBAR, F.; INAL, A.S.; SALTOGLU, N.; BUYUKCELIK, O.; KURTARAN, B.; DUNDAR, I.H. Investigation of the antibiotic susceptibility patterns of pathogens causing nosocomial infections. Saudi Med. J., v.25, n.10, p.1403-1409, 2004.

ZHANEL, G.G.; DECORBY, M.; LAING, N .; WESHNOWESKI, B.; VASHISHT, R.; TAILOR, F.; NICHOL, K.A.; WIERZBOWSKI, A.; BAUDRY, P.J.; KARLOWSKY, J.A.; LAGACÉ-WIENS, P.; WALKTY, A.; MCCRACKEN, M.; MULVEY, M.R.; JOHNSON, J.; CANADIAN ANTIMICROBIAL RESISTANCE ALLIANCE (CARA); HOBAN, D.J. Antimicrobialresistant pathogens in intensive care units in Canada: results of the Canadian National Intensive Care Unit (CAN-ICU) study, 2005-2006. Antimicrob. Agents Chemother., v.52, n.4, p.1430-1437, 2008.

Received for publication on $18^{\text {th }}$ July 2014 Accepted for publication on $17^{\text {th }}$ May 2016 